\title{
Prijateljstvo kao vrlina u praksi medicinske sestre $u$ odnosu na Aristotelovu etiku
}

1 Marija Brdarević

1 Zrinka Pranjić Kozlek

1 Zdravstveno veleučilište Zagreb

„Amicita pares aut accipit aut facit.”

Aristotel

(Prijateljstvo ili prihvaća jednake ili ih takvima čini, tj. prijatelji su ljudi sličnih osobina.)

\section{Sažetak}

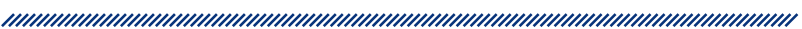

Glavno je obilježje iskrenog i zrelog prijateljstva zajedništvo. lako je još Aristotel rekao da nitko ne bi odabrao život bez prijatelja iz brojnih razloga, danas ta tvrdnja nije ništa manje istinita. U procesu humaniziranja medicine jačanje prijateljstva kao vrline nasuprot jakom prodoru tehnologije poticajni je oblik razvoja vlastite osobnosti. Osim kompetencija znanja i vještina struke, medicinska je sestra kvalitetni procjenitelj procesa zdravstvene njege, edukator, provoditelj istraživanja $\mathrm{i}$ uspješni komunikator. Uspjeh ne ovisi samo o tehničkom napretku struke nego i o zajedničkom cilju svih zdravstvenih profesija, a to je ozdravljenje bolesnika. Opseg djelovanja svih članova tima ovisi o ostvarivanju temeljnih moralnih vrednota kao što su: pravednost, istina, časnost, mudrost, ljubav, strpljivost, skromnost, brižnost, suosjećajnost, ljudska toplina i prijateljstvo. Prema Aristotelu, fenomeni i značajke prijateljstva kao što su: dobrohotnost, uzajamnost, stalnost ili vjernost, jakost i zajedništvo žele potaknuti svaku osobu na poštivanje vrijednosti drugih osoba. Promišljanja u tekstu koji slijedi prikazat će kratki životni put Aristotela, gdje je značajno da je uvijek bio vođen težnjom za znanjem. Sadržaj njegovih spisa dokaz je enciklopedijskog znanja i velike svestranosti. Središnji dio teksta prikazat će neke filozofe koji su se bavili tom temom u svrhu isticanja i približavanja vrijednosti prijateljstva. Glavna analiza međuljudskih odnosa iznjedrena je iz VIII. i IX. knjige Aristotelove Nikomahove etike. $\mathrm{U}$ ovom radu ona ima zadatak humanizacije sestrinstva. Zaključak bi trebao opravdati hipotezu: ako je čovjek (medicinska sestra) pravi prijatelj i djeluje po naravi benevolentne ljubavi, intervencija pravde nije potrebna.

Ključne riječi: prijateljstvo, profesionalni razvoj medicinskih sestara, izvrsnost, bioetika i vrlina

Datum primitka: 13.04.2017.

Datum prihvaćanja: 01.06.2017.

DOI: $10.24141 / 3 / 1 / 10$

Adresa za dopisivanje: Marija Brdarević Zdravstveno veleučilište Mlinarska 38, 10000 Zagreb, Hrvatska

E mail: marija.brdarevic@zvu.hr Tel: +38514595800 


\section{Uvod}

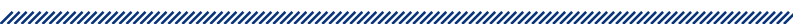

Provjereno je shvaćanje da je za najbolju praksu potrebno najbolje teorijsko znanje. Kuda posegnuti za njim, ako ne u kolijevku civilizacije? Stari Grci cijenili su mudrost. S obzirom na pritisak i pretrpanost današnjeg čovjeka enormnom količinom informacija i načinom života gdje je bit svih problema u krizi morala, treba poći na izvore mudrosti. Smjer koji je nužno iznjedriti uvijek ponovno bitka je kako danas smanjiti „šefovanje” i „bolesni ego” te ,ja” pretvoriti u „mi” i „zdrav ego”. Način je samo jedan, ponovno probuđeno zanimanje za vrline i njihovo življenje. Čovjek je čudno biće jer neprestano misli o sebi i na sebe. Kao subjekt, sam sebi postaje objekt. Ima dana kada sam sebi postaje problem i pitanje. Kako je moguće da čovjek čovjeku postaje vuk? Želimo li shvatiti život današnjeg čovjeka u vremenu i osluhnuti bilo duhovnih smjerova, moramo odgovoriti na pitanje: u kakvoj situaciji i u kakvom to vremenu živi današnji čovjek? Odgovor na ovo pitanje gubi se u strahu i nesigurnosti. Bogata literatura s područja prirodnih znanosti, posebno ekologije, ukazuje na kulturni pesimizam i apokaliptični strah od tehnološke kulture. Svijet postaje hladan i krut te prisiljava na pasivnost kao jedini mogući izlaz. Potiče cinizam i licemjerje. Izbjegavaju se osobni i bliski kontakti među ljudima, gubi se identitet $\mathrm{i}$ osobno „ja”, što je pravi smisao čovjekove slobode. Današnji čovjek mnogo zna, svjestan je toga da mnogo zna i svjestan je toga što želi, ali pogubio se u smislu onoga što on jest. Zaglibio je u egoizam, ludost, izoliranost, tvrdoglavost i žurbu. S druge strane, dostigao je veliki napredak koji rezultira manipulacijama, očajem i licitacijom osjećaja. Svemu tome potreban je lijek trijeznog promišljanja, zdravog suda i razborite ljubavi. Današnjem svijetu i čovjeku potrebna je ispravna dijalektika razuma $\mathrm{i}$ srca, inteligencije $\mathrm{i}$ emocija. Jednostavnije rečeno: čovjeku današnjice potrebna je hladna glava i vruće srce. ${ }^{1}$ Sigurno znamo da je čovjek biće zajednice. Ne može živjeti sam. Čovjek mora procijeniti svoje ponašanje i djelovanje u susretu s drugima. Na pitanje s početka uvoda odgovaramo novim pitanjima: kako živjeti? Kako se vladati i djelovati? Što znači pitati? To znači stupiti u dijalog s nekim (poznatim ili nepoznatim). Kako bismo pronašli sebe, spoznali ili doživjeli to nepoznato tj. pronašli svjetlo $u$ tami, netko nam je nužan. Samo druga osoba pokraj nas može nam olakšati muke i sumnju. Jedni je uvjet za ispravno rješenje tih temeljnih pitanja da ta osoba bude prijatelj.
Aristotelova etika slična je grčkoj medicini. ${ }^{2}$ Ravnoteža i umjerenost uvjeti su da čovjek bude sretan i živi skladno. Ako vlada prijateljstvo, nema opasnosti za nestanak pravednosti. To je temelj svakog života u zajedništvu. Prijateljstvo je nezaobilazna tema i potreba u životu i radu medicinskih sestara. Ono rasvjetljava mnoge dvojbe o vrijednostima drugih osoba, posebno bolesnih i nemoćnih. Vrijednosti drugih osoba oplemenjuju nas i usavršavaju.

Rad ističe veliku svestranost filozofa znanstvenika Aristotela, ali i daje smjernice svakoj medicinskoj sestri u novoj epohi profesionalnog razvoja. Novi izazov u profesionalnom razvoju medicinskih sestara svakako je recept za izvrsnost u timskom radu. Kontinuitet, prenošenje znanja i iskustva, poticanje kompetitivnosti i prepoznavanje kvalitete, mogućnost davanja najboljeg, kao i poticanje drugih da daju najbolje, hrabrost za propitivanje novog i nepoznatog, a iznad svega ljubav prema poslu, recept je za izvrsnost Odjela kardiokirurgije KBC-a Zagreb, prema profesoru Bojanu Biočini, koji je sa svojim uspješnim timom dosegnuo iznimna postignuća i svjetsku prepoznatljivost. ${ }^{3}$ Opseg djelovanja svih članova tima ovisi o ostvarivanju temeljnih moralnih vrednota kao što su: pravednost, istina, časnost, mudrost, ljubav, strpljivost, skromnost, brižnost, suosjećajnost, ljudska toplina i prijateljstvo. Ovaj mali rad ima cilj istaknuti da prijateljstvo kao vrlina može izgraditi kvalitetne odnose $s$ drugim ljudima, što je nezaobilazna tema i potreba u praksi medicinske sestre. Osim kompetencija, znanja i vještina struke, medicinska je sestra kvalitetna procjeniteljica procesa zdravstvene njege, edukatorica, provoditeljica istraživanja i uspješna komunikatorica. Njezina uloga ima poslanje dijaloškog mosta jer često ima ulogu posrednika ili štita u relacijama u timu kojemu pripada. Uspjeh ne ovisi samo o tehničkom napretku struke nego i o zajedničkom cilju svih zdravstvenih profesija, a to je ozdravljenje bolesnika. ${ }^{4}$ Danas se bolesnici suočavaju s više bolesti istovremeno te sa sofisticiranim liječenjem koje je često kontradiktorno i nužno ga je provoditi dugo titrirajući velik broj terapijskih zahvata i lijekova zajedno. U tom je vremenu razumijevanje i prijateljstvo kao vrlina u sestrinskoj praksi poželjno na razini dobrohotnosti (benevolentiae) uz bolesnika gdje nema izlječenja već samo djelomičnog ozdravljenja koje omogućava bolesniku kvalitetniji život i zadovoljstvo životom bez obzira na (ne)potpunost životne funkcionalnosti. Provođenjem zdravstvene njege medicinske sestre neizbježno ulaze u intimni prostor svakog bolesnika i o njegovu povjerenju i otvaranju ovisi i liječenje. Ovim radom želi se skromno 
dodati lekcija o filozofiji zdravstvene njege kako bi znanje iz Aristotelove etike o prijateljstvu pojačalo prijateljski i topli pristup svakom bolesniku uz visokokvalitetno stručno znanje.

\section{Životni put Aristotela}

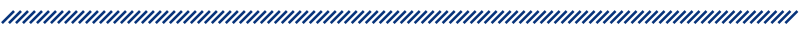

Antička filozofija i Aristotel (384. - 322. pr. Kr.) rodili su znanost i znatno razvili i usmjerili europsku kulturu. lako je bio Platonov učenik, suprotstavlja se njegovim učenjima o idejama, koristi se osjetilima i oblikuje filozofiju prirode. Unosi red u pojmove, stvara stručni jezik kojim se mnoge znanosti i danas koriste. Utemeljuje logiku kao znanost. Vrhunac doseže svojim učenjem o čovjeku i zajednici. Tvrdi da čovjek može biti sretan samo ako primjenjuje sve svoje sposobnosti i mogućnosti. Bio je rodom iz današnjeg prostora Makedonije, a otac Nikomah bio je liječnik. Njegova znanstvena istraživa- nja bila su širokog dometa, a filozofske špekulacije vrlo duboke. Učitelj koji i danas inspirira generacije znanstvenika bio je strastveni promicatelj otkrivanja istine i povećanja količine ljudskog znanja. Vjerovao je da „svi ljudi teže znanju po naravi". ${ }^{5}$ Dok je Platon želio izaći iz spilje i promatrati vječni svijet ideja, Aristotel je proučavao ribe, žabe, biljke šumarice i makove. Filozofija za njega nije bila neka apstraktna disciplina, već sveopća i svestrana potraga za znanjem. U Ateni je osnovao svoju filozofsku školu Licej koja je prozvana peripatetičkom jer su učenici učili šetajući. Nakon dvanaest godina zbog političkih razloga Aristotel napušta Atenu, a školu preuzima Teofrast. Njegovi spisi obuhvaćaju široko znanstveno područje, pokazuju koliko je cijenio prijateljstvo, neovisnost i ponos na čovjekove sposobnosti. Tijekom srednjeg vijeka arapski i kršćanski mislioci rado su proučavali njegovo učenje i u mnogim svojim djelima jednostavno su ga zvali Filozof. Misaonim genijem čini ga spekulativna sinteza naspram majstorskog poznavanja fenomena prirode i ljudske zajednice. Filozofija nije samo ljubav prema znanju, nego je i praktična djelatnost kao težnja prema boljem životu i volja svakog čovjeka da najbolje realizira tu svoju čovječnost. Upravo u tom

\begin{tabular}{|c|c|c|}
\hline \multicolumn{3}{|r|}{ Aristotelovi spisi } \\
\hline & PODRUČJE & NAZIV DJELA \\
\hline I. & Logički & Organon (Kategorije, Prva i druga analitika, Topika, De interpretatione) \\
\hline II. & Prirodoznanstveni i matematički & $\begin{array}{c}\text { Fizika } \\
\text { Oduši } \\
\text { Onebu } \\
\text { Meteorologica }\end{array}$ \\
\hline III. & Filozofski, psihološki i metafizički & $\begin{array}{l}\text { Metafizika - prva filozofija } \\
\text { De philosophia } \\
\text { Protreptikos (Nagovor na filozofiju) } \\
\text { De divinatione per somnum } \\
\text { De memoria } \\
\text { De insomniis }\end{array}$ \\
\hline IV. & Etički i politički (filozofija ljudskog života) & $\begin{array}{c}\text { Nikomahova etika } \\
\text { Eudemova etika } \\
\text { Državnik, De iuventute } \\
\text { Politika, Atenski ustav (De generatione et corruptione) } \\
\text { Magna Moralia }\end{array}$ \\
\hline V. & Estetički & $\begin{array}{c}\text { O retorici } \\
\text { O pjesničkoj umjetnosti } \\
\text { Sophistici Elenchi }\end{array}$ \\
\hline
\end{tabular}


aspektu nalazi se poveznica Aristotelove težnje prema višem dobru (etičkim krepostima) i djelovanju medicinske sestre prema bolesniku. ${ }^{6}$ Ono što Aristotel želi poručiti u istraživanju sestrinske etike nije samo znanje i promatranje, nego bolje ponašanje u zajednici. S vrlinama se ne rađamo. Njih treba učiti, stjecati, posjedovati i primjenjivati. Zadatak je svake medicinske sestre poticati svakog čovjeka (kolegice, bolesnike i prijatelje) prema vrlinama. Ono što je zajedničko grčkoj filozofiji i filozofiji sestrinstva jest želja učiniti ljude boljima. Kako steći to umijeće?

Opsežna i bogata djela Aristotela sastoje se od mnogih pojedinačnih spisa i danas se dijele prema izdanju I. Bekkera (Berlin, 1831.). Smatra se da jedan dio potječe od samog učitelja, a drugi su dio učeničke zabilješke $s$ predavanja. Za razumijevanje Aristotelove filozofije u Hrvatskoj zaslužni su: M. Belić, B. Bošnjak, D. Pejović, A. Pažanin, J. Talanga i dr., a za prijevod njegovih djela posebno je zaslužan T. Ladan. ${ }^{6}$ Mnoge Aristotelove misli vrlo su vrijedne, ali one se nastavljaju kao njegova kritika prethodnih filozofa: elejaca, Parmenida, Zenona i Melisa. Tako Guthrie smatra da je Aristotel posljednji od antičkih i prvi od modernih filozofa. ${ }^{7}$

Pretpostavlja se da je većina spisa koji su došli do našeg modernog doba kao Aristotelovi zaista i Aristotelovi. $^{7}$ Andronik je sakupio i izdao Aristotelova djela. Nije jasna sudbina Aristotelovih spisa nakon njegove smrti. Prema nekim antičkim izvorima (Strabon i Plutarh), nisu bili dostupni sve do 1. st. pr. Kr., kada ih je Sula donio u Rim, gdje ih je prepisao te ponovno izdao Andronik s Roda. O vjerodostojnosti te priče, kao i o točnoj Andronikovoj ulozi, postoje mnoge dvojbe. U svakom slučaju, jasno je da tek nakon 1. st. pr. Kr. Aristotelovi ezoterični spisi počinju dobivati oblik u kojem ih danas čitamo te da od toga razdoblja možemo govoriti o formiranju Corpusa Aristotelicuma (tablica 1). ${ }^{8} \mathrm{U}$ 1. st. pr. Kr. Andronik je složio i katalogizirao djela, a tako i postao zaslužan za neke nazive koje je imenovao iz prostornog razloga ( $t a$ meta ta physica) pa je „prva filozofija” postala „metafizika" jer je te knjige stavio na policu iznad fizike. Taj naziv zaživio je u znanosti kao nauka o „prvom uzroku” svih stvari. Tako se događaj prostorne pohrane djela poklopio s čuvenom temom „prvog nepokrenutog pokretača" koji je za Aristotela prvi uzrok svega što postoji, a semantički se danas povezuje s „Apsolutom” ili Bogom. Prema Aristotelu, država bi trebala biti savršenost zemaljskog morala i vrednota. U svojem djelu Politika Aristotel iskazuje svoje poznate odredbe da je čovjek političko biće (grč. zoon politikon) i da ne može živjeti bez države te da je i govorno biće koje se realizira u međudjelovanju s drugim ljudima. Zajednica ljudi nije skup neovisnih pojedinaca, jer se vlada prema etičkom imperativu prijateljstva, što znači solidarnost i suživot. ${ }^{6}$ Važno određenje čovjeka prema Aristotelu jest da je on jedino živo biće koje svojim govorom „priopćuje korisno i štetno, pa tako i pravedno i nepravedno. Jer to je, nasuprot ostalim životinjama, ljudima svojstveno, da jedino oni imaju sjetilnu zamjedbu dobra i zla, pravednog i nepravednog i slično. A zajedništvo takvih tvori dom i grad. Po naravi je pak prvotniji grad negoli dom i svaki pojedini od nas. Jer cjelina je nuždno prvotnija od dijela." (Politika 1253a 15-20.) ${ }^{9}$ Kada bi postojalo prijateljstvo među svim ljudima, kada bi se svi zalagali za opće dobro, onda država ne bi trebala imati zakone, vladala bi pravda i time se prijateljstvo smatra temeljem državnog zajedništva. Osnovna ljudska prava za slobodu pojedinca ne postavljaju se odlukom većine, ona već postoje u naravi čovjeka, a državni ih ugovor može u krajnjoj mjeri priznati, proglasiti i tumačiti, mudro zaključuje Aristotel iz svojeg bogatog znanja o poznavanju ustava i državnog prava antičkog svijeta. $\mathrm{U}$ etici Aristotel ističe nekoliko etičkih pravila. Čovjek je dobar kada postupa obzirno i traži ispravan razum. U Nikomahovoj etici važne su etičke vrline koje govore o vladanju uma nad strastima kao što su hrabrost, pravednost, samosvladavanje, predanost, velikodušnost, plemenitost duše, časnost, blagost, istinitost, uljudnost i prijateljstvo te vrline uma koje se tiču funkcije uma u njemu samome, kao što su mudrost i razboritost. Ove vrijednosti čine idealnu sliku čovjeka i mora ih utjeloviti kako bi živio lijepo, ispravno i razumno. Cijela grčka etika želi odgovoriti na pitanje: što je sreća (eudajmonizam, grč. eudaimonia - etički pravac koji zastupa da su motiv, svrha i cilj ljudskog djelovanja u postizanju i unaprjeđivanju vlastite i tuđe sreće) $)^{5}$ ? Aristotel odgovara: „Sreća je u aktivnom djelovanju, a ne u pasivnom uživanju." Sreća nije u zadovoljstvu ili užitku, ni u materijalnom posjedovanju, nego u čovjekovu djelu. ${ }^{5}$

Kako to može pomoći medicinskim sestrama u praktičnom radu s bolesnicima? Posebno je važno da medicinske sestre u svojem mentalnom pristupu razdvoje svaku osobu od njezina djela i ponašanja. Koja je posebna vrijednost ljudskog života i zajedništva? Svako je ljudsko biće dragocjeno, dobro, loše ili posve čangrizavo. Vrijednost ljudskog života ukorijenjena je u onome što jesmo, ne gubi se ako sklizne ispod određene razine inteligencije, pokretljivosti ili svjesnosti. U tom su smislu medicinske sestre prve u pomaganju i služenju bolesnima i potrebitima jer bolesnici dolaze, osim sa svojim bolestima, i sa svojim životnim problemima pa im je po- 
trebna sveobuhvatna i fizička i psihološka podrška. Poželjno je imati uz bolesnog čovjeka sretnu medicinsku sestru. Iz tih potreba nužno je više nego ikad uskladiti i integrirati odgojni i obrazovni element u sestrinstvu. Moramo priznati da gomilanje nepreglednoga stručnog znanja i znanstvenih činjenica ne rezultira nužno i odgovornom moralnom orijentacijom. Trajna bioetička edukacija i njezina implementacija u svakodnevni rad medicinske sestre može pomoći u izgradnji i širenju moralnosti na djelu, ali i unaprjeđenju međuljudskih odnosa. ${ }^{10}$ Prema Aristotelu, u sretnom ozračju i druge osobe postaju sretne ili uz dobre osobe i drugi postaju dobri u konkretnom kontekstu. Holistički pristup sadrži sestrinsku posvećenost bolesniku koja budi nadu, ali ukazuje na veliku krizu i potragu za srećom. U toj potrazi tražimo i odgovore filozofa o značenju prijateljstva kroz ovaj rad. Cilj je potaknuti autonomno etičko promišljanje medicinskih sestara i preuzeti odgovornost za svoje ponašanje i svoj rad.

\section{Aristotel o prijateljstvu u Nikomahovoj etici}

Najvažnije pitanje u Aristotelovo doba bilo je: kako treba živjeti da bi se živjelo sretno? Već je u staroj Grčkoj bilo je jasno, kao i danas, da se ljudski život u svakom obliku može potrošiti, rasuti. Život je pozornica gdje se ljudski životi ostvaruju ili promašuju. Sreća je način života koji uključuje vrline. Vrline se mogu ostvariti dje-

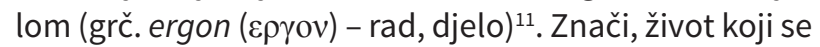
realizira kroz vrline najbolje je djelo na koje smo usmjereni. Ta usmjerenost ne smjera na promjenu mjesta, nego na promjenu osobe. Za ostvarenje tog cilja (grč.

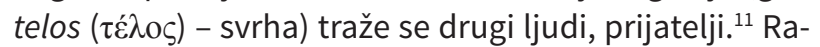
spravu o prijateljstvu Aristotel započinje tvrdnjom da je prijateljstvo najnužnije za život: „Bez prijatelja nitko ne bi htio živjeti, pa makar imao svega drugoga u izobilju. U nevoljama, prijatelji se drže jedinim utočištem...ako idu dvojica zajedno, lakše mogu misliti i raditi." jateljstvo je vrlina koja je važna za osobni rast svakog čovjeka. Prijatelji žele dobro jedan drugome. Aristotel razlikuje tri vrste prijateljstva: prijateljstvo iz koristi, prijateljstvo iz zadovoljstva i prijateljstvo kao vrlinu. Prve dvije vrste obično prestaju čim nestaju ugoda i korist. Najdublja su i najtrajnija prijateljstva odnosi obostrane dobrohotnosti gdje je svaka osoba potaknuta brigom za dobro drugoga. Takvo prijateljstvo traje sve dok su oba prijatelja dobri i dok postoji želja činiti dobro svojem prijatelju radi njega samog. Najčešća su prijateljstva iz ugode i koristi koja su pozitivna, ali nisu dovoljna za sretan život.

James M. Cooper navodi četiri razloga zašto Aristotel kaže da nam je za dobar život potrebno društvo prijatelja:12

1. prijateljstvo je važan izvor svjesnosti i samorazumijevanja.

2. prijateljstva nas zaštićuju od dosade kojoj su podložne čak i najzanimljivije aktivnosti

3. sudjelujući u aktivnostima s drugima, možemo u njih biti uključeni u znatno većoj mjeri nego što bismo bili da to činimo sami

4. bez njih ne možemo postati dobri (najvažniji razlog). Prvi je razlog bolja samoprocjena, a ona ne dolazi izravno, nego upravo posredstvom prijatelja. Drugi je razlog prepoznavanje vlastitog karaktera, gdje u svojem prijateljstvu vidimo odraz vlastitog života kao u zrcalu. Bez podrške i odobrenja drugih ne bismo shvatili važnost svojih briga i planova. Kad smo prisiljeni raditi sami, bez obzira na to koliko je neka aktivnost vrijedna, činjenica je da ćemo se prije umoriti. Treći je razlog da sve aktivnosti koje se ističu vrlinama u prijateljskom ozračju i nas potiču da vodimo krepostan život. Upravo je taj razlog medicinskim sestrama blizak jer je u etici skrbi granica između onoga tko pruža skrb i onoga tko tu skrb prima fluidna, što znači da se činjenje dobra za drugoga izjednačava s činjenjem dobra za sebe samoga. Četvrti je razlog najvažniji, jer Aristotel kaže da se možemo vježbati u vrlinama radeći i živeći s dobrim ljudima. Prijateljstvo nije samo pojedinačna vrlina, nego odnos po kojemu ljudi postaju dobri. Zajedničko zanimanje i zajednička vrijednost daje razlog osobama da bi zadobili ono što nisu sposobni sami postići. ${ }^{1}$

S obzirom na to da postoje razne vrste ljudi, među njima postoje i razna prijateljstva. Je li nužna jednakost među prijateljima? On drži da ne mogu biti prijatelji oni između kojih je prevelika razlika. Najuža veza postoji između pravde i prijateljstva. ${ }^{11} \mathrm{U}$ petoj knjizi Nikomahove etike Aristotel višeznačno raspravlja o pravednosti. $\mathrm{S}$ jedne strane izjednačava pravednost $\mathrm{s}$ poštivanjem zakona i vrlinom. „Razboritost nema ovlasti nad mudrošću. Niti nad boljim dijelom duše, kao ni liječništvo nije iznad zdravlja: jer ona se ne služi mudrošću, nego se trsi oko njezina nastanka." (EN1144a5-10.)13 S druge strane postoji razlika u odnosu na vrlinu, gdje kaže da je vrlina nekakvo stanje, a pravednost relacija „prema 
drugome". Razlika između vrline i pravednosti temelji se na drugoj odrednici pravednosti, korelativnosti. Ta je vrsta pravednosti nazvana „općom” pravednošću. Druga je tzv. „partikularna” pravednost koja podržava pravila jednakosti i samo je dio vrline. „Partikularna” se pravednost, po Aristotelu, dijeli na: a) diobenu ili distributivnu - gdje će se dobit dijeliti prema zaslugama te ovisno o zaslugama može biti jednaka i nejednaka; b) druga je paradigma pravde korektivna ili komutativna pravednost. Distributivna pravednost vodi računa o dostojanstvu ljudi i veličini njihovih zasluga za zajednicu, a komutativna smanjuje razliku između građana i čini ih jednakima pred zakonom. Tako je moralnost povezana s polisom. Zajednica u potpunosti ovisi o prijateljstvu, što spaja etiku i politiku. Drugim riječima, prijateljstvo je ostvarena pravednost, a cilj društva nije samo stvaranje materijalnih uvjeta, nego realizacija dobrog života. Iskustvo vlastite egzistencije potvrđuje da pred prijateljima stojimo kao pred sobom. ${ }^{13} \mathrm{U}$ zajedništvu je važno opće dobro, što ne znači da pojedinačna dobra nisu potrebna. „Tko po prirodi nije svoj, već je tuđi, on je od prirode rob iako je čovjek." Gdje vlada prijateljstvo nije potrebna intervencija pravde. „Pravednost (iustitia, pravičnost) je vrlina na temelju koje svatko ima ono što mu pripada i kako zakon nalaže." (1366b7.)14 Želja za prijateljstvom rađa se brzo, ali ne i prijateljstvo. Aristotel naglašava čovjekovu potrebu za prijateljstvom u različitim razdobljima života (mladi, stariji), različitim okolnostima (bogati, siromašni) i pokušava pomiriti egoizam i altruizam. Nužno je „voljeti sebe”, ali ne na samoljubiv način, gledajući na korist i ugodu, već na plemenit način (poklanjajući i novac i pažnju). Postoje dvije vrste samoljublja: dobro i loše (dužni smo voljeti sebe, koliko je moguće, ali tako da budemo dobri prema ljudima oko sebe). Prijateljstvo između dobrih ljudi zaštićeno je od klevete. Zli se ljudi ne mogu radovati jedni drugima, osim kad je u pitanju korist. „Ljudi su većinom zaboravljivi, više vole da im se dobro učini negoli da ga sami čine." Čovjek je stvaralačko biće i opstoji svojom djelatnošću. Stoga on ljubi svoje djelo jer ljubi opstanak. ${ }^{13}$ Primjer su za to umjetnici koji stvarajući pjesme, slike ili tonove vole svoja djela i žive za njih kao za svoju djecu. Važnije je djelovati nego posjedovati. Medicinske sestre često ističu da im je najveće zadovoljstvo zahvalnost bolesnika koju prepoznaju u stanju i ponašanju pacijenta nakon njihovih intervencija. Prijatelj može biti osoba koja strpljivo prihvaća ponašanje druge osobe i zna čuvati tajnu. Aristotel priznaje da čovjek ne treba imati ni premalo ni previše prijatelja, već onoliko koliko je najbolje za zajedništvo. Prijatelj je nužniji u nesreći, no ugodnije je i ljepše imati ga u sreći. Prijateljstvo je zajedništvo i jasno je da prijatelji dijele ono sve što čini zajedničko življenje.

Dobra medicinska sestra u svojem profesionalnom rastu ponovno potvrđuje (otkriva) stare i otkriva (potvrđuje) nove vrijednosti koje se pojavljuju u novim okolnostima omogućenima tehnički sve zahtjevnijim poslovima, ali i sve većim poštivanjem autonomije pacijenta. Ona je kreposna (dobra, plemenita, strpljiva, požrtvovna, predana i altruistična). Sve što radi usmjereno je dobrobiti bolesnika.

\section{Prijateljstvo kao pojam u povijesti filozofije i kao potreba u praksi medicinske sestre}

„Prijateljstvo umanjuje bol i tugu. Svaki istinski prijatelj želi svome prijatelju: 1. da postoji i živi; 2. svako dobro; 3. činiti mu dobro; 4. uživati u njegovoj prisutnosti; 5 . podijeliti s njim vlastite radosti i žalosti, živeći s njim jednim srcem." - sv. Toma Akvinski

$\mathrm{U}$ današnjoj kulturi dominira formalizam i individualistički utilitarizam te nije jednostavno prihvatiti značajke i fenomene prijateljstva kroz zauzetost za drugoga, kako nas uči Aristotel. Ipak, nadu nam daje praksa medicinskih sestara čiji je glavni zadatak poboljšati kvalitetu života bolesnog čovjeka. Očito je da bolestan čovjek današnjice pati od osamljenosti i straha od smrti, a nije rijetko da se medicinska sestra nađe kao njegova suputnica uz krevet u dugim noćima zbog svoje zahtjevne službe. Autorice žele podijeliti misaone poruke i svjedočanstva mnogih bolesnika u teškim fazama njihovih bolesti koji su upućeni svim ljudima, a možemo ih sažeti u raskošne hvalospjeve o prijateljstvu koje tako dobro tumači Aristotel i neki filozofi uz njega i kasnije. Biti usamljen usred gomile ljudi nije ničiji izbor, a posebno u bolesti i nevolji. Nitko ne bi izabrao živjeti bez prijatelja, makar posjedovao sve ostale dobre stvari.

U tekstu koji slijedi izabrani su neki od mnogih filozofa koji su govorili o prijateljstvu, ali i o važnosti koju je Aristotel pridavao prijateljstvu kao vrlini. Središnja definicija Aristotelova određenja vrline nastala je kao apologija tvrdnje nepoznatog autora: „Ljudi su dobri jednim načinom, zli svakovrsno.” Aristotel odgovara: „Dakle, krepost je stanje s izborom, zapravo srednost 
u odnosu prema nama, a određena načelom, naime onim kojim bi je odredio razborit čovjek. Ona je srednost između obaju poroka, onoga prema suvišku i onoga prema manjku; a i zbog toga što poroci ili ne dostižu ili premašuju potrebnu mjeru u čuvstvima i djelatnostima, dok krepost i nalazi i izabire sredinu. Otuda, prema bivstvu te odredbi koja govori što je ona u biti, krepost je srednost, ali prema najboljem i pravednom, ona je krajnost." (EN1106b36-1107 a2-8.) ${ }^{13}$

Aristotelu je prijateljstvo najviši od svih etičkih ideala, a kršćanstvo mu je dodalo „agape” (od grč. ó $\gamma \alpha \pi \alpha ́ \omega$ cijeniti, ljubiti), govor o bezuvjetnoj ljubavi prema Bogu i bližnjemu, i time još uzdiglo na vrhunaravni etički ideal. ${ }^{11}$ Nakon Martina Luthera (1483. - 1546., njemački, teološki i vjerski reformator, začetnik protestantske reformacije) ${ }^{15}$ prijateljstvo se opet počelo promatrati kao „naravna ljubav prema samom sebi. Najradikalniji stav iskazao je Sören Kierkegaard (1813. - 1855. utemeljitelj egzistencijalizma, rođen i živio u Kopenhagenu). Kierkegaard je vjerovao da nijedan sustav mišljenja ne može objasniti jedinstveno iskustvo pojedinca, ${ }^{11}$ mišlju da je prijateljstvo naravni fenomen koji ne sadrži etički zahtjev. Ako je središnji pojam etike odanost, onda tema o prijateljstvu ne bi smjela izostati. U grčkoj filozofiji ta tema predstavljala je model zdrave relacije među ljudima. Shvaćala se kao kozmički princip i davala mjerilo za ljudski suživot. Empedoklo (oko 490. pr. Kr. - 430. pr. Kr., grčki predsokratovski filozof sa Sicilije) je igru prijateljstva usporedio s vatrom koja se suprotstav-

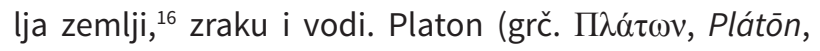
428. ili 427. pr. Kr. - 347. ili 348. pr. Kr., rođen i umro u Ateni, iznimno utjecajan grčki filozof, idealist, Sokratov učenik, Aristotelov učitelj i osnivač Akademije) zaključuje da ljudi loših karaktera ne mogu biti prijatelji jer nisu prijatelji ni sami sebi. ${ }^{11}$ Aristotel je rekao da nitko ne bi odabrao život bez prijatelja i da većina od nas očekuje iskreno zajedništvo, što se protivi mišljenju Thomasa Hobbesa, engleskog filozofa iz 17. stoljeća. ${ }^{12}$ Važne elemente o prijateljstvu iznijeli su neki filozofi kroz povijest, ali zbog obima ovog rada bit će naglašeni samo neki nezaboravni. Aurelije Augustin (lat. Aurelius Augustinus Hipponensis; Tagasta, 13. studenoga 354. Hippo, 28. kolovoza 430., sjevernoafrički pisac, glazbeni teoretičar, teolog i jedan od najutjecajnijih kršćanskih učitelja i filozofa tijekom 1600 godina, u razdoblju između Aristotela i T. Akvinskog) ${ }^{12}$ razvija Aristotelovu misao te iz „filia” (prijateljska ljubav) pretače u „agape“ (bezuvjetna ljubav). Za Augustina u prijateljstvu iz dviju nastaje jedna duša. Dok Aristotel drži da je krepost koju prijatelji opažaju jedan drugome ona koja ih zbli- žava, Augustin smatra da prijatelje zbližava Bog. Toma Akvinski (oko 1225. - 1274., jedan od najpoznatijih filozofa kršćanske skolastike, jedan od prvih filozofa koji je napravio sintezu Aristotelove i Platonove filozofije te ih povezao s kršćanstvom ${ }^{11}$ želi nadopuniti njegovu misao i smatra da u prijateljstvu s čovjekom Bog dijeli život, a ljubav koja se razvija iz tog dijeljenja s nama zove se milosrđe. Najvažnije su značajke prijateljstva Tome Akvinskog: dobrohotnost (lat. bonevolentiae), uzajamnost, stalnost ili vjernost, javnost i zajedništvo. Immanuel Kant (22. travnja 1724. - 12. veljače 1804., njemački filozof i geograf) kaže: „Prijateljstvo je zaduženje dviju osoba prema jednakoj i obostranoj ljubavi i poštivanju." Tvrdi da znanje stječemo i iskustvom i razumijevanjem. Kant je svoje etičko učenje iznio u djelu Kritika praktičnog uma 1788. godine. $U$ tumačenju etike Kant polazi od pojma dobre volje. Za njega je to dobro po sebi, bez ikakvih ograničenja, koje ima za svrhu jedino ispunjenje dužnosti, odnosno poštivanje zakona. Moralno se djelovanje zasniva na samokontroli jer svaki čovjek već ima apriorni zakon koji nam naređuje kako da se ponašamo. Taj moralni zakon Kant naziva kategoričkim imperativom. Kant je dao više definicija kategoričkog imperativa. Jedna je od njih: „Radi tako da princip tvojega rada može postati princip rada svih drugih." Osim ove najopćenitije formulacije moralnog zakona, Kant navodi i sljedeće načelo: „Djeluj tako da tretiraš ljude, kako sebe tako i druge, uvijek kao cilj, a nikad kao sredstvo!" Time Kant naglašava dužnost poštivanja posebnog dostojanstva čovjeka kao razumnog i slobodnog bića. Po Kantu, moralna dobrota nekog ljudskog čina ne slijedi iz objekta, tj. ništa nije dobro samo po sebi. Uostalom, smatra da niti ne možemo znati kakve su zapravo stvari u sebi. Moralno dobro nekog čina zato po Kantu slijedi jedino iz dobre nakane. Sama je nakana pak dobra jedino ako se radi iz dužnosti, tj. da bismo poštivali moralni zakon. Mada svaki čovjek ima u svojoj svijesti moralni zakon, o njegovoj volji ovisi hoće li ga poštovati ili ne. ${ }^{12}$ Kant daje prostora emocijama, ali izdvaja moralno prijateljstvo koje shvaća kao potpuno povjerenje dviju osoba. Znamo koliko je danas u vremenu nesigurnosti i moru informacija važno da bolesnik ima povjerenje u medicinsku sestru. Kant sugerira da prijateljstvo ima značenje zadovoljenja različitih ljudskih potreba i interesa, a osobita povezanost vuče partikularnost u jedinstveno i tvori odnos dviju i više osoba te olakšava njihov suživot. Što je znanje o prijateljstvu dublje i potiče razmišljanje medicinske sestre to ona postavlja zahtjevnije i više standarde u svojoj praksi. Provođenje procesa zdravstvene njege uvjetovano je medicinskim i biološkim znanjem i multidisciplinarnim pristupom, 
a prijateljstvo ulazi u sve pore i segmente osobe koja radi u timu, emotivno vraća osobu na duhovna izvorišta te ju jača u suživotu s drugima. Posao je medicinskih sestara pristup osobama na granici života i smrti, jedine izvjesnosti koja sestrinskoj profesiji daje ozbiljnu težinu i odgovornost. Integrativni model sestrinstva sadrži sve etičke teorije i principe sestrinske etike te čini most između sestrinstva kao znanosti i zdravstvene njege koja uključuje specifične vještine - tehne..$^{10} \mathrm{U}$ tom je mostu Aristotelov model vrlina u kojem prijateljstvo i pravednost imaju ključnu ulogu dobrodošao. Prijateljstvo kako ga predstavlja Aristotel pomaže medicinskim sestrama osvijestiti moralni aspekt pojedine praktične situacije, pronaći uzrok problema i dobronamjerno izabrati najbolje moguće rješenje. Uključujući znanje iz praktične filozofije uz specijalne vještine - tehne stvaramo sestrinstvo kao znanost $u$ interdisciplinarnom i multidisciplinarnom ozračju. Toliko više danas u praksi medicinskih sestara Aristotel i znanje o različitim filozofima koji govore o prijateljstvu imaju važnu ulogu u stvaranju boljega vrijednosnog sustava i realizaciji ljubavi prema životu. Prijateljstvo kao prirodni fenomen predstavlja model zdrave relacije među ljudima i mjerilo je za ljudski suživot. Aristotel pita: Gdje se nalazi prijateljstvo? I odgovara: „Prirodno prijateljstvo goji diete prema roditeljima i roditelji prema djetetu, ne samo kod ljudi nego i kod ptica i kod većine životinja, između onih koji su iste vrste, ali osobito među ljudima. Zato hvalimo prijatelje ljudi (philanthropous). I u zabludama možemo vidjeti, kako je uzko i prijateljski jedan čovjek povezan s drugim. Ali i gradove i države ujedinjava prijateljstvo, i zakonodavci više nastoje oko njega negoli oko pravde. Istomišljenost naime slična je prijateljstvu, a za njom najviše teže, te bunu tjeraju iz grada i države kao neprijateljstvo. Prijatelji ne osjećaju potrebu pravde. Oni, koji su pravedni među sobom, žele imati i međusobno prijateljstvo. Ovo je pravednima najmilije. Ne samo nuždno, nego i lijepo je prijateljstvo. Prema mnogima jedna od liepih stvari, gojiti prijateljstvo. Neki smatraju, da su isto dobri ljudi prijatelji."13 Prirodno prijateljstvo razvija i utvrđuje širinu granice, medicinskim sestrama olakšava jačanje emocionalne inteligencije, a samim tim i ubrzava donošenje odluka u nekim sestrinskim problemima i dvojbama gdje je nužna empatija i asertivno ponašanje.

\section{Zaključak}

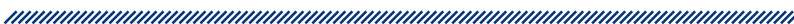

Govoreći o prijateljstvu najfiniju analizu međuljudskih odnosa daje nam upravo Aristotel. Interpersonalnost je prva i najvažnija instancija čovjekova ostvarenja u svijetu prema drugom čovjeku tj. osobi. Prijateljstvo je karakteristika osoba, a osoba je najviši stupanj bitka (bitak - lat. esse - bíti, unutarnji princip bića, ono po čemu biće opstoji, dobiva egzistenciju, zbiljnost bića). Bitak iznutra daje subjektu svaku odliku, za razliku od bîti - lat. essentia, što je oznaka materijalnog bića. Bitak i bit u svakom su konkretnom biću ujedinjeni, a razlikuju se metafizički. Aristotelovski bitak i bit, zajedno čine bivovanje - egzistenciju). ${ }^{11}$ Ostale su karakteristike sloboda, odgovornost i ljubav. Sve one ne mogu nikada biti vlasništvo ili stvar. Tako dobivamo apsolutne vrednote od kojih je ljudski život na prvom mjestu. Najvrjedniji je međuljudski odnos upravo prijateljstvo i ljubav. Prijateljstvo se razlikuje od ljubavi po tome što ljubav sadrži strast, a prijateljstvo duševnu hranu pa iz toga proizlazi da se želja za prijateljstvom brzo rađa, ali samo prijateljstvo ne, mudro zaključuje Aristotel..$^{13}$ Ako je čovjek prijatelj i djeluje po naravi dobrohotne ljubavi, intervencija pravde nije potrebna. U suprotnom, u zajednici sa zakonom čovjek je najplemenitije biće, a bez zakona divlja zvijer. Čovjek je sretan ako se koristi svim svojim sposobnostima i mogućnostima, ali kao biće zajednice, u sklopu moralnih normi, prijateljstvo sve povezuje u cjelinu.

Posao medicinskih sestara javan je i častan jer ljude usmjerava jedne prema drugima. U svim razdobljima života, u bolesti, mlade čuva, a starijima pruža uslugu i pomoć tamo gdje iz nedostatka snage sami nisu u stanju nešto učiniti. Prijateljstvo je temelj svakog zajedništva i pridonosi općem dobru. Kvalitetnu medicinsku sestru odlikuju nesebičnost, ljubav i žrtva, što su i osobine prijateljstva. Takvo prijateljstvo rješava probleme, daje sigurnost, mir i čini nas sretnijima. Krajnje je vrijeme da se sestrinstvo približi javnom prostoru, posebno njegov dio koji jača humanizaciju relacije bolesnik - medicinska sestra - zajednica. Nužno je hitno prevladati animozitet i povezati sve sestrinske institucije te formirati zajedničku kritičnu masu koja će snažno pokrenuti pozitivne korake u profesionalizaciji. ${ }^{17}$ Nazočnost u javnosti jest popularizacija profesionalizacije struke, ali i korak $\mathrm{k}$ rješavanju gorućih problema povezanih $\mathrm{s}$ obrazovanjem i praksom, što je prevelika tema za opseg ovog rada. U novoj epohi paternalistički vrijedno- 
sni model prelazi u holistički, preciznije autonomni. Taj prijelaz u današnjem turbulentnom vremenu otvara prostor za diskusiju, ali i prijateljski dijalog o moralnim dvojbama, gdje tako možemo pronaći više rješenja za isti ili sličan problem. Univerzalnog rješenja nema, ali kroz prijateljski odnos lakše je poštivati autonomiju bolesnika i paternalizam zdravstvenog tima, kao i prepoznati njihove etičke granice. Prijateljstvo je put prema prepoznavanju načela važnih za izbor i odluku samog bolesnika. ${ }^{18}$ Malo usvojenog znanja o Aristotelovoj etici pomoći će jačanju izvrsnosti medicinskim sestrama u kvalitetnijem radu i jednostavnijem izražavanju. Prijateljstvo u plemenitom smislu pomaže nadići koristoljublje i hedonizam u svakom radu, neposrednom kontaktu i komunikaciji s bolesnikom. Medicinskim sestrama nedostaje otvorenosti i hrabrosti da o tome dovoljno progovore. U tom će smislu Aristotel svojim stavovima pomoći jačanju spone između bolesne osobe, medicinskih sestara i zajednice. Njihova je potreba i prisutnost nezamjenjiva, čuvajmo ih i ne dajmo da odu iz Hrvatske.

„Verae amicitae sempitermae sunt - Prava su prijateljstva vječna", rekao je Ciceron.

\section{Literatura}

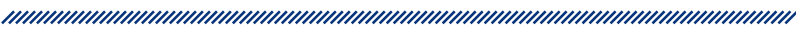

1. Koprek I. Kao dio mene - etika, prijateljstvo, krepost. Zagreb: Hrvatsko filozofsko društvo; 1995.

2. Barnes J. Aristotel. Zagreb: Kruzak; 1996.

3. Ars medica - hrabrost za izvrsnost, dokumentarni film, HTV1, 2015. Dostupno na: http://mojtv.hr/kanal/tv-program/1/htv1/2016-02-17/emisija/73595439/poglediars- medica--hrabrost-za-izvrsnost-dokumentarni-film. aspx (pristupljeno 11. travnja 2017.).

4. Matulić T. Identitet, profesija i etika sestrinstva. Dostupno na: https://www.scribd.com/doc/26323729/identitet-profesija-i-etika-sestrinstva (pristupljeno 11. travnja 2017.).

5. Aristotel. Metafizika. Zagreb: Hrvatska sveučilišna naklada; 1992.

6. Aristotel. U: Hrvatska enciklopedija. Dostupno na: http:// www.enciklopedija.hr/natuknica.aspx?id=3834 (pristupljeno 25. svibnja 2017.).

7. Guthrie WKC. Povijest grčke filozofije. Aristotel: sučeljavanje. Zagreb: Naklada Jurčić; 2007.

8. Androniks Roda. U: Hrvatska enciklopedija. Dostupno na: http://www.enciklopedija.hr/natuknica.aspx?id=2666 (pristupljeno 25. svibnja 2017.).

9. Aristotel. Politika. Zagreb: Hrvatska sveučilišna naklada; 1992.

10. Kalauz S. Etika u sestrinstvu, Zagreb: Medicinska naklada; 2012.

11. Mišić A. Rječnik filozofskih pojmova. Split: Verbum; 2000.

12. Magee B. Povijest filozofije. Zagreb: Mozaik knjiga; 2010.

13. Aristotel. Nikomahova etika. Zagreb: Sveučilišna naklada Liber; 1982.

14. Aristotel. Retorika. Zagreb: Naprijed; 1989.

15. Theologian, Biography. Dostupno na: http://www.biography.com/people/martin-luther-9389283 (pristupljeno 11. travnja 2017.).

16. Empedoklo. U: Hrvatska enciklopedija. Dostupno na: http://www.enciklopedija.hr/natuknica. aspx?id=17844 (pristupljeno 11. travnja 2017.).

17. Čović A, Gosić N, Tomašević L. (ur.).Od nove medicinske etike do integrativne bioetike. Zagreb: Hrvatsko bioetičko društvo, Pergamena; 2009: 247.

18. Kalauz S. Sustav moralnih vrednota u sestrinskoj praksi u Hrvatskoj. Usp. Kalauz S. Sestrinska profesija u svjetlu bioetičkog pluriperspektivizma. Zagreb: Pergamena; 2011: 204-224. 


\section{FRIENDSHIP AS A VIRTUE IN THE PRACTICE OF NURSES IN RELATION TO ARISTOTLE'S ETHICS}

\author{
1 Marija Brdarević \\ 1 Zrinka Pranjić Kozlek \\ 1 University of Applied Health Sciences Zagreb
}

„Amicita pares aut accipit aut facit.“

Aristotle

(Friendship either accepts equals or makes them as such, ie., friends are people of similar characteristics.)

\section{Abstract

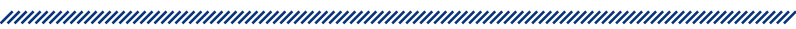

The main characteristic of a sincere and mature friendship is the unity. Even though Aristotle himself said that no one would have chosen a life without friends for a number of reasons, today this statement bears no less significance. In the process of humanizing medicine, strengthening friendship as a virtue with a strong intrusion of technology is a stimulating form of development of one's own personality. Besides the competences, knowledge and skills of the profession, a nurse assesses the quality of the nursing care process, educates, conducts research and successfully communicates. Success depends not only on the technical progress of the profession but also on the common goal of all health professions - and that is the restoration patient's health. The scope of activities of all members of the team depends on the exercise of fundamental moral values such as justice, truth, honorableness, wisdom, love, patience, humility, caring, compassion, warmth and friendship. According to Aristotle the phenomena and features of friendship such as benevolence, solidarity, permanence or loyalty, strength and unity want to encourage each person to respect the values of others. The following reflections will display the short life path of Aristotle where he was always considerably driven by the desire for knowledge. The content of his writings gives evidence of the encyclopedic knowledge and great versatility. The central part of the article will present some philosophers who have studied this subject for the purpose of highlighting and making the value of friendship more familiar. The main analysis of human relations has emerged from the book VIII and IX of Aristotle's Nicomachean Ethics. In this paper, it has the task of humanizing nursing. The conclusion should justify the hypothesis: if a person (a nurse) is a true friend and acts in accordance with benevolent love, the intervention of justice is not required.

Keywords: friendship, professional development of nurses, excellence, bioethics and virtue 